\title{
NEMATODE COMMUNITY RESPONSE TO VARIED PROPORTION OF DECOMPOSING PLANT LITTER
}

\author{
Anita R Sholeha, ARdHini R MaHARning, ERIE K NASUTION
}

Faculty of Biology, Universitas Jenderal Soedirman, Jalan dr. Suparno 63 Purwokerto, Indonesia 53122

\section{A B S T R A C T}

The research objectives were to investigate nematode community response to decomposing plant litter of varying proportions, and to measure the litter decomposition rate. This greenhouse experiments included three treatments of decomposing plant litter with proportions of 30:70, 50:50, and 70:30 (leaf litter to stem-paddy litter, weight to weight), and two controls (commercial organic fertilizers and no-organic matter). We applied the prepared plant litter and organic fertilizers on the surface of the agricultural sandy soil. Soil samples were taken after two, seven, 14, 28, 49, and 77 days to follow nematode temporal changes. Nematodes were assigned to functional groups and family level of a taxon. We used Anova to test the significance of nematode abundance among the treatments, exponential decay model to measure decomposition rates of the plant litter, and canonical correspondence analysis to investigate the correlation of varying plant proportion and nematode community composition. The results showed that nematode functional groups and family did not differ among soils of various plant litter proportions. Bacterivorous Rhabditidae and Cephalobidae, fungivorous Aphelenchidae, and fungivorous-root feeder Tylenchidae inhabited plant litter amended soils. Their abundance, however, differed significantly $(\mathrm{p}<0.001)$ and revealed two temporal patterns, i.e., linear $(50: 50)$ and unimodal $(30: 70$ and $70: 30)$. No nematodes were observed in organic fertilizer amended soil and no-organic matter soil. Nematode community composition changed over time according to the litter proportion, in which by the end of experiments, community of 50:50 and 30:70 were the least similar (r: 0.57 of axis-1 and 0.54 of axis-2, CPV: 89.06). We concluded that all litter proportions retained similar quality and supported the growth of similar nematode groups. The litter proportion, however, appeared to influence nematode abundance, their temporal patterns, and community compositions.

KEY WORDS: plant litter proportion, decomposition rate, nematode community, nematode temporal patterns

Corresponding author: ARDHINI R MAHARNING | email: ardhini.maharning@unsoed.ac.id

\section{N T RO D U C T I O N}

The free-living nematodes are microfauna that contribute significantly to the soil decomposer food web. They occupy various trophic levels and play important roles in the soil food web. The nematodes might be divided into bacterial-feeder, fungal-feeder, omnivore, and predator (Bongers \& Bongers 1998) (Morriien, 2016), which also conveniently separates them into the functional groups (Bongers \& Bongers 1998). Depending on their environment, some functional groups may present while others are absent.

Changes in nematode community structure might reflect the changes in their interaction within the community, which, in turn, influence the soil process in the habitat. Nematodes also affect microbe biomass due to their feeding activity, which provides greater mineralized nitrogen compared to mineralization by microbes in the limited nitrogen environment (Ferris \& Bongers 2006; Neher et al., 2012).

Nematodes quickly respond to soil disturbance and soil nutrient enhancement by affecting microbe activities, thus changing the relative abundance of bacterivorous nematodes (Ferris et al., 2004; Morriien, 2016). The quality of organic matter as a valuable resource for microbes appears to determine their community and activity. The high litter quality, commonly indicated by its low C:N, more likely decomposes faster than low litter quality with high C:N (Murray et al., 2006; Powers et al., 2009; Szanser et al., 2011; Morriien, 2016). The difference in litter quality might support a different community of soil microbes. Thus, a mixture of various plant litter quality might trigger the activity of different species of microbes that eventually influence nematode community. This research was intended to investigate the response of nematode community to different proportion of plant litter types, and to measure the litter decomposition rate as one indicator of soil processes.

\section{METHODS}

These greenhouse experiments were done by applying the the organic matter to the agricultural sandy soil to follow nematode community response and the rate of litter decomposition. The soil was sampled after two, seven, 14, 28, 49, and 77 days. The nematodes were collected according to Baermann funnel method (Forge \& Kimpinski, 2008) and identified their functional groups and family taxon according to Tarjan et al. (1977), Freckman \& Baldwin (1990), Bongers \& Bongers (1998), and Nguyen (2009). The functional groups followed Yeates et al. (1993) and Forge \& Tenuta (2008). The decomposition rate was measured with litter bag experiment according to Harmon et al. (1999).

The organic matter selected were commercial organic fertilizers ( $\mathrm{C}: \mathrm{N}=15.2)$, and various types of plant litter consisted of peanut leaves ( $\mathrm{C}: \mathrm{N}=7.64$ ), cassava leaves (C:N =9.45), banana leaves ( $\mathrm{C}: \mathrm{N}=16.94)$, long bean stems $(\mathrm{C}: \mathrm{N}=$ 23.46), and paddy plants ( $\mathrm{C}: \mathrm{N}=31.46)$. They were cut into small pieces and combined with the various proportions of plant litter to create microhabitat availability for soil organisms. We employed three different proportions (weight to weight) of plant litter types. These were the mixture of 30: 70 (S2), 50:50 (S3), and 70:30 (S4) leaf litter to stem-paddy litter. Organic fertilizer amendment (S1) to the sandy soil and no-organic matter addition (S0) were the experimental controls. 
Prior to soil application, the plant litter (S2, S3, and S4) were inoculated with soil organisms and decomposed for two weeks (Maharning \& Irianto, 2012).

The sandy soil taken from agricultural land was placed into the experimental box $(40 \times 30 \times 10 \mathrm{~cm})$ with $5 \mathrm{~cm}$ depth after sundried for approximately a week. The prepared plant litter and organic fertilizers were applied on the sandy soil surface (100 g per box). The total sample units were 150 ( 5 treatments, 5 replicates, 6 periods). Each box was sprayed with $100 \mathrm{ml}$ of water every day to maintain the soil moisture. The soil temperature, $\mathrm{pH}$, and moisture were measured at the same time the soil was sampled for the nematodes.

Litter bag experiments were conducted to follow the litter weight loss. Each litter bag was filled with $5 \mathrm{~g}$ of plant litter mixture (S2, S3, and S4). The bags were buried under the soil in the experimental box. The litter bags were retrieved at the same time as soil sampling. The litter was burnt with muffler furnace $\left(450^{\circ} \mathrm{C}, 4\right.$ hours) to obtain the ash weight. The calculation of the decomposition rate followed the exponential decay model (Harmon et. al., 1999).

The data were analyzed with ANOVA to examine the significant difference of the nematode abundance according to the treatments. We applied the canonical correspondence analysis (CCA) to investigate the nematode community composition change as the response of organic matter amendment, soil temperature, $\mathrm{pH}$, and moisture.

\section{RESULTS AND DISCUSSION}

Rhabditidae, Cephalobidae, Aphelenchidae and Tylenchidae were nematode families observed only in soil amended with plant litter (S2, S3, and S4). There were no nematodes observed in soil with organic fertilizer (S1) and soil with no-organic matter (S0). Based on the functional groups, Cephalobidae and Rhabditidae were bacterivores, Aphelenchidae was fungivores, and Tylenchidae was both fungivores and root feeders (Bongers \& Bongers, 1998; Yeates et. al., 1993; Forge \& Tenuta, 2008). Their abundance across the treatments was significantly different $(p<0.001)$.

The pattern of nematode abundance in $S 2$, over time, was similar to that of S4 in which their number peaked at day 28 then decreased (Figure 1a and 1c). S3 showed an entirely different pattern with increasing number of nematodes after 77 days (Figure 1b). Despite the difference pattern shown by S3, it was clear that the bacterivorous Rhabditidae determined the pattern in all treatments with plant litter. The overall abundance reached 71 and 50 individuals.g- ${ }^{-1}$ soil after 28 days in S2 and S4, respectively, then declined to approximately 20 individuals. ${ }^{-1}$ soil after 77 days. In contrast, their number increased to 102 individuals. ${ }^{-1}$ soil at the end of the experiment for S3. Bacterivorous Cephalobidae was the second largest nematode family inhabit the plant litter treated soil of S2 and S3. In S4, it was the fungivorous Aphelenchidae.

The decomposition rates of the plant litter were not significantly difference $(p>0.05)$ (Figure 2). Plant litter of S2 showed the rate of $0.0095 \%$.day $^{-1}$ of mass loss $\left(p=0.005, \mathrm{R}^{2}=0.86\right)$. It was 0.0151 and 0.0154
$\%$ day $^{-1}$ for S3 $\left(p=0.002, \mathrm{R}^{2}=0.93\right)$ and S4 $(p=0.004$, $\mathrm{R}^{2}=0.95$ ) respectively.
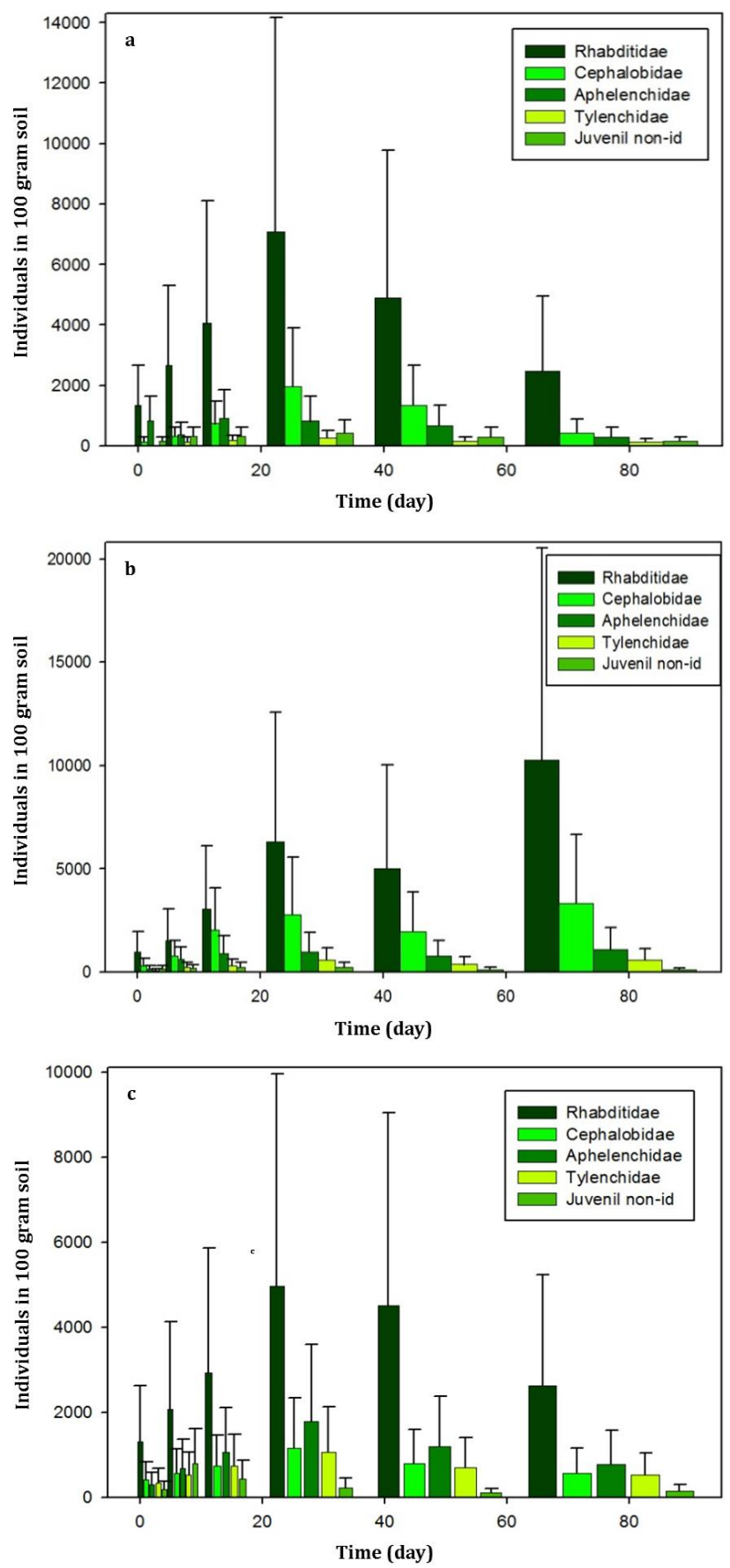

Figure 1. Nematode abundance in agricultural sandy soil amended with leaf litter, stem-paddy litter over time. (a) proportion of 30:70 (S2), (b) proportion of 50:50 (S3), and (c) proportion of 70:30 (S4) (mean $\pm S D, n=5)$.

Overall analysis of CCA revealed the correlation of 0.57 (axis-1) and 0.54 (axis-2) with the cumulative percent variance of 89.06 . This analysis suggested that although the changes of nematode community were mostly accounted for the different proportion of plant litter, soil moisture, $\mathrm{pH}$, and temperature, other uncovered environmental factors such as $\mathrm{C}$ and $\mathrm{N}$ soil or biotic factor might also contribute significantly to the nematode community changes. At the beginning of the experiments (day 2), nematodes of each plant 
litter amended soil (S2, S3, and S4) demonstrated different community composition. After 7 and 14 days, the community of S3 changed and was quite distinct from the others, but after 28 days, the community in S4 developed differently from S2 and S3. At this time community of S2 and S3 responded to the decomposing plant litter similarly. At the end of experiments, S2 and S3 communities showed the most different nematode composition (Figure 3).

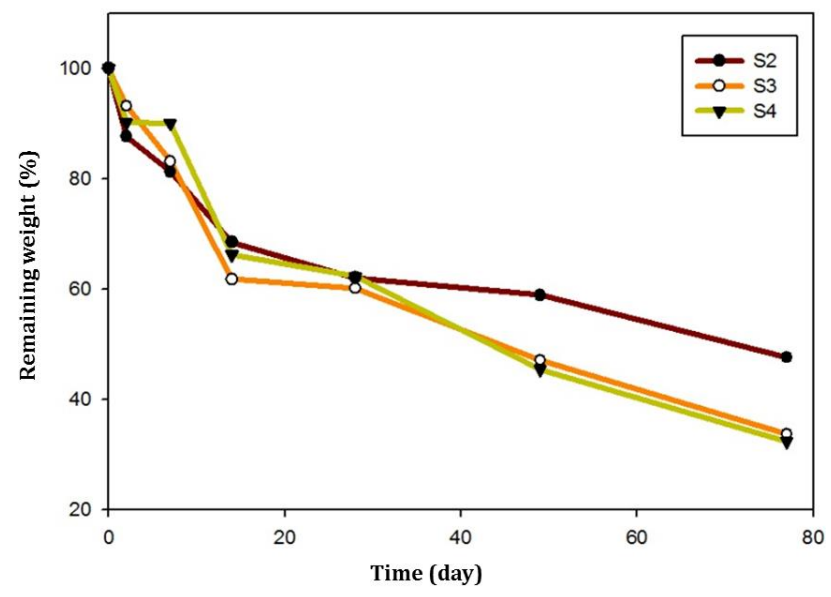

Figure 2. The remaining weight of plant litter amended in agricultural sandy soil with the proportion of 30:70 (S2), 50:50 (S3), and 70:30 (S4) of leaf litter to stem-paddy litter.

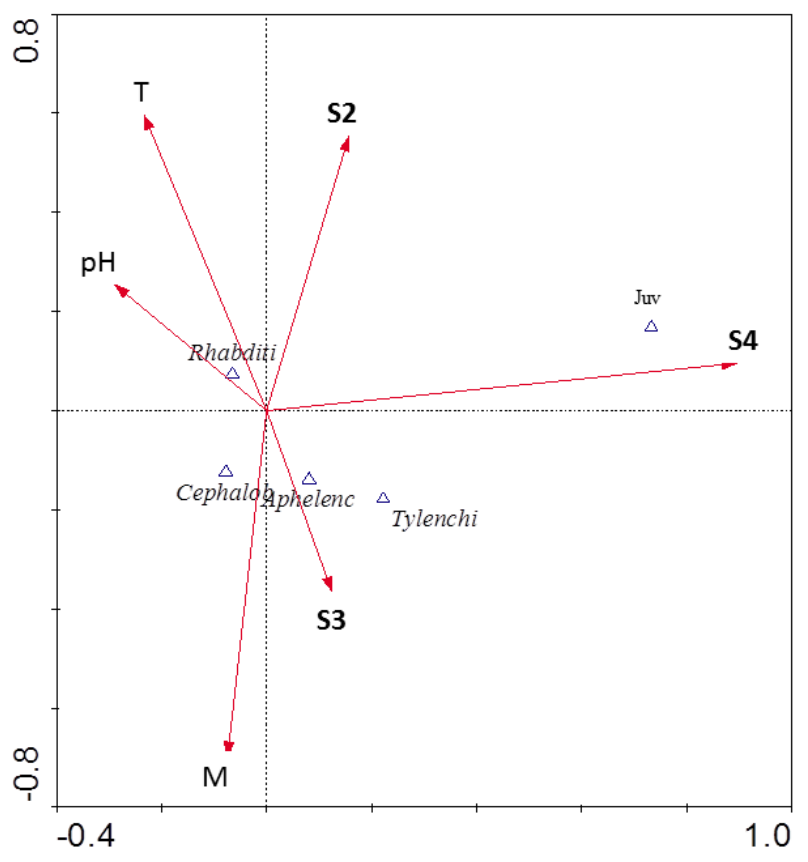

Figure 3. CCA bi-plot revealed the correlation of the environmental factors (plant litter proportion, soil $\mathrm{pH}$, temperature, and moisture) with the nematode families after 77 days (r of axis-1: 0.52, axis-2: 0.46, CPV: 91.5\%)(T: soil temperature, M: soil moisture, $\mathrm{pH}$ : soil $\mathrm{pH}, \mathrm{S} 2$ : proportion of 30:70, S3: proportion of 50:50 S4: proportion of 70:30 leaf litter to stem-paddy litter, Rhabditi: bacterivorous Rhabditidae, Juv: juvenile nematodes, Tylenchi: fungivorous and root-feeder Tylenchidae,

Aphelenc: fungivorous Aphelenchidae, Cephalo: bacterivorous Cephalobidae)
The results showed that the free-living soil nematodes inhabited agricultural sandy soil amended with plant litter but not in those amended with organic fertilizers. This data suggested that soil nematodes might have disappeared from the organic fertilizers due to lack of plant litter that created microhabitat. Sandy soil amended with varying proportion of plant litter capable of maintaining a high number of nematodes (50-102 individuals.g- ${ }^{-1}$ soil). This abundance was greater than that reported by Briar et al. (2011) who observed abundance of 1824 individuals.g-1 ${ }^{-1}$ soil with large macro-aggregates. Our greenhouse experiments with plant litter amendment also supported more nematode than organic farming soil with 30 individuals.g-1 (Briar et al., 2007)

The different proportion of plant litter did not coincide with changes in functional groups or nematode families. Nematodes do not feed directly on the plant litter but consume bacteria or fungi colonizing the litter (Bongers \& Bongers, 1998; Morriien, 2016). Bacteria and fungi were the primary decomposers and served as basal resources for nematodes (Morriien, 2016). In our experiments, decomposition in the plant litter suggested bacteria and fungi colonized and grew in the litter. Therefore, bacterivorous and fungivorous nematodes were common in the treatments of decomposing plant litter because of the food availability. There were no omnivorous or predaceous nematodes observed in this experiment.

The different proportion of plant litter, nevertheless, supported the different abundance of the nematodes, and revealed the distinctive pattern of abundance over time. Bacterivorous Rhabditidae and fungivorous Aphelenchidae were opportunistic groups of nematodes. They were numerous in enriched environments (Bongers \& Bongers 1998) as in this greenhouse experiment. Tylenchidae was a family most commonly inhabited the stable environment (Ferris et al., 2001), Therefore, they were relatively low in abundance in our experiments. The similar proportion between the leaf litter and stem-paddy litter (50:50) stimulated the increase of nematode abundance up to 77 days suggesting suitable habitat and efficient use of the resources. This finding might support the concept of soil biota enhancement or recovery. The other two litter proportions showed nematode abundance decrease after reaching maximum at day 28. They occupied by different second dominant family i.e., bacterivorous Cephalobidae (30:70) and opportunistic fungivorous Aphelencidae (70:30).

It was not clear as for how 30:70 and 70:30 produced different temporal patterns of nematodes from the 50:50 proportion, although all proportion of litter types showed similar quality as indicated by their decomposition rates $\left(0.0095-0.0154 \%\right.$ day $\left.^{-1}\right)$. It was possible that different nematode species might live in microhabitat created by 50:50 litter proportion. 
This suggestion requires a detailed study on the species level that provides higher resolution of a taxonomic level.

Hodge et al. (2000) reported peak of nematodes abundance after seven days then decrease on Lolium perenne litter (C:N $=12.2)$ and earthworms (Lumbricus terrestris) (C:N = 4.1) during the period of 30 days experiments. In addition, for 70 days decomposition experiments, it required 14 days for bacterivorous and fangivorous nematodes to increase in Crotolaria juncea litter (C:N = 18.9). Temporal changes were observed in agricultural soil enhanced with soybean, corn, wheat, and paddy straw litter for four years (Briar et al., 2007).

The diversity was low regarding functional groups and family level of a taxon. The decomposition rates were also similar among the different litter proportions. The temporal patterns and community compositions, however, were quite distinct. These were most likely correlated to the plant litter proportion ( $\mathrm{r}$ : 0.57-0.54). Changes in chemical composition in decomposing plant litter over time might lead to nematode community changes. More study examining the changes in the chemical component in decomposing litter and nematode species would provide a clear explanation.

\section{O N C L USI O N}

The varied proportions of plant litter did not affect their rates of decomposition, suggesting similar litter quality of the three different mixtures. This condition supported the growth of similar nematode functional groups and family. However, the litter proportion seemed essential for nematode abundance and their temporal pattern. The balanced mixture between leaf litter and stem-paddy litter increased the overall nematode abundance and showed a linear pattern over time, while their abundance in the other two proportions demonstrated the unimodal pattern. The nematode community composition changed variably depending on the litter proportion. Their composition was quite differed by the end of experiments, in particular between those of soil with 50:50 and 30:70.

\section{ACKNOWLEDGMENTS}

This research was an undergraduate research project funded by the grant provided for Dr. Maharning by Universitas Jenderal Soedirman. For this, the authors would like to express their gratitude to the university.

\section{RE F ERE N C ES}

Bongers T, Bongers M. 1998. Functional diversity of nematodes. Appl. Soil Ecol. 10:239-251.

Briar SS, Fonte SJ, Park I, Six J, Scow K, Ferris H. 2011. The distribution of nematodes and soil microbial communities across soil aggregate fractions and farm management systems. Soil Biol. Biochem. 43:905-914.
Briar SS, Grewal PS, Somasekhar N, Stinner D, Miller SA. 2007. Soil nematode community, organic matter , microbial biomass and nitrogen dynamics in field plots transitioning from conventional to organic management. 37:256-266.

Ferris H, Bongers T. 2006. Nematode indicators of organic enrichment. In: Journal of Nematology. Vol. 38. p. 3-12.

Ferris H, Bongers T, De Goede RGM. 2001. A framework for soil food web diagnostics: Extension of the nematode faunal analysis concept. Appl. Soil Ecol. 18:13-29.

Ferris H, Bongers T, de Goede RGM. 2004. Nematode faunal analyses to assess food web enrichment and connectance. Nematol. Monogr. Perspect. 2:503-510.

Forge TA, Kimpinski J. 2008. 'Nematodes.' In M.R. Carter \& E.G. Gregorich, eds. Soil Sampling and Methods of Analysis. Second ed. CRC Press. pp.415-24.

Forge TA, Tanuta M. 2008. Indicator of soil food web properties. In M.R. Carter dan E.G. Gregorich (Ed), Soil sampling and methods of analysis. CRC Press, pp.577-88

Freckman DW, Baldwin JG. (1990) Nematoda. In: Dindal DL (ed) Soil biology guide. Wiley, New York, pp 155-200

Harmon ME, Nadelhoffer KJ, Blair JM. 1999. 'Measuring Decomposition, Nutrient Turnover, and Stores in Plant Litter.' In Robertson, G.P., Coleman, D.C., Bledsoe, C.S., and Sollins, P. eds. Standard Soil Methods for Long term Ecological Research. Oxford University Press. pp.202-240.

Hodge A, Stewart J, Robinson D, Gri BS, Fitter AH. 2000. Plant N capture and microfaunal dynamics from decomposing grass and earthworm residues in soil. 32:1763-1772.

Maharning AR, Irianto A. 2012, 'Soil Biota Application to Improve Soil Quality: Habitat Formation, Soil Biota Diversity, and Soil Food-Web.' Report. Faculty of Biology, Universitas Jenderal Soedirman, Purwokerto

Morriien E. 2016. Understanding soil food web dynamics, how close do we get? Soil Biol. Biochem. 102:10-13.

Murray PJ, Cook R, Currie AF, Dawson LA, Gange AC, Grayston SJ, Treonis AM. 2006. Interactions between fertilizer addition plants and the soil environment: Implications for soil faunal structure and diversity. 33:199-207.

Neher D a., Weicht TR, Barbercheck ME. 2012. Linking invertebrate communities to decomposition rate and nitrogen availability in pine forest soils. Appl. Soil Ecol. 54:14-23..

Nguyen, B., (2009). Rhabditida: Rhabditina Generic Identification. [Online] Available at: "http://nematology.ifas.ufl.edu/ nguyen/ morph/rhabdi/rhabmain.htm"http://nematology. ifas.ufl.edu/ nguyen/morph/rhabdi/rhabmain.htm.

Powers JS, Montgomery RA, Adair EC, Brearley FQ, DeWalt SJ, Castanho CT, Chave J, Deinert E, Ganzhorn JU, Gilbert ME, et al. 2009. Decomposition in tropical forests: a pan-tropical study of the effects of litter type, litter placement and mesofaunal exclusion across a precipitation gradient. J. Ecol. 97:801-811.

Szanser M, Ilieva-Makulec K, Kajak a., Górska E, Kusińska a., Kisiel M, Olejniczak I, Russel S, Sieminiak D, Wojewoda D. 2011. Impact of litter species diversity on decomposition processes and communities of soil organisms. Soil Biol. Biochem. 43:9-19.

Tarjan AC, Esser RP, Chang SL. 1977. An Illustrated key to nematodes found in Fresh Water. Journal Water Pollution Control Federation 49:2318-2337 accessed 05.05.14. as Interactive Diagnostic Key to Plant Parasitic, Freeliving and Predaceous Nematodes at. http://nematode.unl.edu/ key/ nemakey.htm.

Yeates GW, Bongers T, de Goede RGM, Freckman DW, Georgieva SS. 1993. Feeding habits in soil nematode families and genera-an outline for soil ecologists. Journal of Nematology. 25:315-331 